\title{
Inoculum Sources, Infection Periods, and Effects of Environmental Factors on Alternaria Brown Spot of Mandarin in Mediterranean Climate Conditions
}

D. D. M. Bassimba, Instituto de Investigação Agronómica (IIA), Chianga, 2104 Huambo, Angola; and J. L. Mira and A. Vicent, Instituto Valenciano de Investigaciones Agrarias (IVIA), Moncada, 46113 Valencia, Spain

\begin{abstract}
Bassimba, D. D. M., Mira, J. L., and Vicent, A. 2014. Inoculum sources, infection periods, and effects of environmental factors on Alternaria brown spot of mandarin in Mediterranean climate conditions. Plant Dis. 98:409-417.

Alternaria brown spot (ABS), caused by Alternaria alternata, is a serious disease affecting mandarin in humid and in semi-arid regions. The information available from Florida cannot be easily extrapolated to Mediterranean regions; thus, epidemiological studies were conducted during two consecutive years in Spain. Pathogenic isolates were found in the canopy and leaf litter and on weeds of the genus Sonchus. The pathogen survived in fallen immature leaves for up to 76 days, until complete leaf decay. Conidia of Alternaria spp. were captured continuously and pathogenic isolates were detected in all sampling dates. However, the number of pathogenic isolates was not correlated with the total captured, indicating that morphological identification is not

sufficient for airborne inoculum monitoring. In contrast to humid areas, infections occurred mainly in spring and autumn. Classification tree analysis indicated that virtually all infections occurred on weeks with rainfall $\geq 2.5 \mathrm{~mm}$ and average temperature $\geq 12.5^{\circ} \mathrm{C}$. Based on regression quantiles, the amount of rainfall, number of rain days, and total wetness duration were considered important factors increasing ABS incidence during infection periods. The development of decision support systems for ABS control in Mediterranean conditions may benefit from the restricted periods of infection and the strong influence of weather factors in disease onset.
\end{abstract}

Alternaria brown spot (ABS), caused by the "tangerine pathotype" of Alternaria alternata (Fr.) Keissl., is a serious disease of some mandarin (Citrus reticulata Blanco) cultivars. The disease causes necrosis of young leaves, with severe defoliation and twig dieback. On young fruit, the disease appears as corky eruptions and necrotic depressed spots than are often associated with premature abscission and substantial yield losses. On mature fruit, necrotic spots are 1 to $10 \mathrm{~mm}$ in diameter and, although these lesions do not cause fruit rot, the external quality of the fruit is seriously reduced $(34,36)$.

There is no teleomorph known for the fungus and it survives as mycelia in affected plant tissues (34). The pathogen reproduces by means of conidia formed on lesions, which are disseminated by air currents and rain splash and infect susceptible tissues under adequate conditions of temperature and moisture. The pathogen produces a host-specific ACT toxin, which is selective to some mandarin cultivars such as 'Dancy' mandarin and its cultivated hybrids, as well as other mandarins and hybrids such as 'Murcott', 'Emperor', and 'Ponkan'. The effect of the ACT toxin in host cells is extremely rapid, and the time required for symptom expression is very short $(34,36)$.

Symptoms of ABS were first detected in Queensland, Australia, in 1903 affecting Emperor mandarin. The disease is currently widespread in humid citrus-growing regions such as Florida, Brazil, Argentina, Colombia, Cuba, Peru, and China but also causes serious epidemics in semi-arid areas such as Israel, Spain, Italy, Greece, Turkey, Iran, and South Africa $(2,9,12,15,21,34,42)$. In Spain, ABS was first detected in 1998 and spread to all citrusgrowing provinces. The disease affects mainly the late-maturing hybrids 'Fortune' and 'Nova' and is of increasing importance in other recently introduced cultivars (39).

Cultural practices which improve orchard ventilation and prevent the growth of lush foliage can reduce ABS severity in the

Corresponding author: A. Vicent, E-mail: avicent@ivia.es

Accepted for publication 2 October 2013.

http://dx.doi.org/10.1094/PDIS-09-13-0956-RE

(C) 2014 The American Phytopathological Society orchard. However, several fungicide sprays per year are necessary for the economic control of ABS in humid and in semi-arid citrusgrowing regions $(3,26,34,38)$. Due to the short incubation period of the pathogen and the lack of curative activity of the fungicides, the efficacy of control programs is extremely dependent on the proper synchrony between spray timing and infection periods in each region. Therefore, site-specific epidemiological knowledge of the disease is critical to develop efficient fungicide schedules.

Laboratory studies were conducted with the ABS pathogen to evaluate the effects of moisture on conidial production on leaf lesions and the effects of relative humidity, rainfall, irradiation, and vibration on conidial release $(28,35)$. The effects of temperature and leaf wetness on leaf infections have been also experimentally determined $(7,32)$. However, current knowledge about field epidemics, inoculum dynamics, and distribution of infection periods is only available from Florida (33), and no epidemiological studies in the Mediterranean Basin or other semi-arid regions are known. The relationships between environmental factors and ABS severity obtained from these field studies led to the development of the decision support system (DSS) ALTER-RATER, which proved to be effective to estimate the risk of infection and improve fungicide spray timing for ABS control in humid citrus-growing regions in Florida and Brazil $(3,26)$.

In general, Alternaria diseases are characterized by great environmental flexibility and tolerance of a broad range of climatic conditions. Indeed, the geographical range of ABS comprises humid citrus-growing areas characterized by a summer rainfall pattern with about $1,500 \mathrm{~mm} /$ year, as well as Mediterranean regions with rainless summers and annual precipitation rarely over $500 \mathrm{~mm}$ (43). However, as pointed out by Rotem (30), the environmental factors associated with Alternaria diseases and their relative importance in field epidemics may differ greatly depending on the climatic region. Considering the substantial differences between humid and semi-arid citrus-growing areas, epidemiological knowledge about ABS from humid environments cannot be directly extrapolated to Spain or other Mediterranean regions. Thus, to facilitate the development of DSSs to improve the efficiency of current spray programs in Spain, the basic epidemiological features of ABS under semi-arid Mediterranean conditions need to be determined. Thus, the objectives of this study were to (i) to describe the 
inoculum sources and inoculum dynamics of the ABS pathogen and (ii) determine the distribution of infection periods and their relationship with environmental factors under semi-arid Mediterranean conditions in Spain.

\section{Materials and Methods}

Inoculum sources. All studies were conducted in an experimental orchard of the Instituto Valenciano de Investigaciones Agrarias (IVIA) research station at Moncada in Valencia province (Spain). The experimental plot of 0.75 ha was planted in 1998 with mandarin hybrids obtained from crosses with Fortune and Murcott severely affected by ABS. Trees were grafted on 'Carrizo' citrange (Poncirus trifoliata $\times$ C. sinensis) rootstock and planted on a 3-by2-m spacing. The orchard was drip irrigated and the rows had an east-west orientation. Crop management, fertilization, and pest control followed recommended practices, except that fungicides were never applied. Samples of leaves, twigs, fruit, and leaf litter from affected trees, together with leaves of different weeds (Araujia sericifera, Bromus diandrus, Chrysanthemum spp., Convolvulus arvensis, Conyza spp., Cyperus rotundus, Diplotaxis erucoides, Oxalis pes-caprae, Senecio vulgaris, and Sonchus spp.), were collected arbitrarily in the experimental orchards in 2011 and 2012. Ten samples of at least $20 \mathrm{~g}$ were processed for each plant material. All samples were washed under running tap water, surface disinfested for $1 \mathrm{~min}$ in a $1.5 \%$ sodium hypochlorite solution, and washed twice with sterile distilled water. Small pieces of tissue ( 2 to $4 \mathrm{~mm}$ wide) were removed using a scalpel and were placed on potato dextrose agar (PDA) amended with benomyl at $0.5 \mathrm{mg} / \mathrm{ml}$ (PDAb). In total, 15 isolation points each were prepared for each sample. Plates were incubated for 7 days at $23^{\circ} \mathrm{C}$ in darkness, and the Alternaria isolates obtained were transferred to PDA.

Pathogenicity tests were conducted to determine the proportion of colonies belonging to the "tangerine pathotype" of Alternaria alternata. Conidial suspensions were obtained from cultures flooded with distilled water amended with $0.1 \%$ Tween 20 (40). The surface of the colonies was rubbed gently with a sterile spatula and the suspension was filtered through two layers of cheesecloth to separate mycelium from conidia. Spore concentration was adjusted to $10^{5}$ conidia/ml with a hemacytometer. Five detached, immature Fortune leaves about 50\% expanded were sprayed with approximately $2 \mathrm{ml}$ of the spore suspension of each isolate and incubated at $23^{\circ} \mathrm{C}$ in a plastic chamber at approximately $100 \%$ relative humidity $(\mathrm{RH})$ in the dark (40). The reference pathogenic isolate IVIA-A051 isolated from Fortune leaves was used as the positive control and leaves sprayed with distilled sterile water as the negative control. The presence of necrosis on leaves was evaluated after $72 \mathrm{~h}$ of incubation.

The survival of the pathogen on fallen leaves was evaluated in three experiments conducted in 2011 and 2012, starting on 10 May 2011, 9 May 2012, and 10 October 2012. Three groups of recently fallen ABS-affected leaves on the orchard floor were covered with a plastic mesh ( 2 by $2 \mathrm{~m}, 5$-by-5-mm openings) fixed with four stainless-steel pins. Leaf density under each of three plastic nets for symptomatic leaves was adjusted to approximately $150 \mathrm{~g} \mathrm{~m}^{2}$. A sample of approximately $10 \mathrm{~g}$ of leaves was collected at 2- to 3week intervals from each plastic mesh and was surface disinfested as described above. Fifty 5-mm-diameter leaf discs were removed from each sample with a cork borer and were plated on PDAb and incubated for 14 days at $23^{\circ} \mathrm{C}$ in darkness. The Alternaria colonies isolated were transferred to PDA and evaluated for pathogenicity as described above.

Airborne inoculum. The dynamics of airborne conidia were studied in 2011 and 2012 by placing four glass microscope slides ( 26 by $76 \mathrm{~mm}$ ) coated with silicone oil (Merck) in the center of the experimental area. Slides were placed under a plastic rain shelter $(0.3$ by $0.3 \mathrm{~m}) 0.25 \mathrm{~m}$ above the soil surface at a $45^{\circ}$ angle from the horizontal, covering the four cardinal points (6). Microscope slides were changed weekly and treated with lactophenol-acid cotton blue, and a coverslip ( 32 by $22 \mathrm{~mm}$ ) was affixed. Mountings were examined at $\times 400$ magnification and all spores showing the morphological characteristics of Alternaria spp. (31) were counted in four microscope field transects.

Airborne conidia of Alternaria spp. were isolated in the experimental orchard by exposing plates of modified ARSA selective medium (agar at $16 \mathrm{mg} / \mathrm{ml}, \mathrm{KH}_{2} \mathrm{PO}_{4}$ at $1 \mathrm{mg} / \mathrm{ml}, \mathrm{KNO}_{3}$ at $1 \mathrm{mg} / \mathrm{ml}$, $\mathrm{KCl}$ at $0.5 \mathrm{mg} / \mathrm{ml}, \mathrm{MgSO}_{4}$ at $0.5 \mathrm{mg} / \mathrm{ml}$, sodium polypectate at 5 $\mathrm{mg} / \mathrm{ml}$, streptomycin sulfate at $0.5 \mathrm{mg} / \mathrm{ml}$, benomyl at $0.1 \mathrm{mg} / \mathrm{ml}$, thiabendazole at $0.1 \mathrm{mg} / \mathrm{ml}$, and dicloran at $0.1 \mathrm{mg} / \mathrm{ml})(27,35)$. Each month during 2011 and 2012, eight plates were placed on the soil surface near the spore trap at a $45^{\circ}$ angle from the horizontal covering the four cardinal points (6). Plates were exposed for $1 \mathrm{~h}$ in the orchard and then incubated for 1 week at $23^{\circ} \mathrm{C}$ in the dark. Colonies of Alternaria growing on each plate were transferred to PDA and incubated for 2 weeks at $23^{\circ} \mathrm{C}$ under a 12-h photoperiod. Pathogenicity tests were conducted as described above.

Infection periods. Infection periods were determined during 2011 and 2012 by placing sets of three trap plants of Fortune and Nova in the experimental area each week. Trap plants were 2-yearold trees grafted on Carrizo citrange grown in plastic pots $(250 \mathrm{~mm}$ in diameter by $200 \mathrm{~mm}$ deep) containing potting mix (75\% peat and $25 \%$ sand $[\mathrm{vol} / \mathrm{vol}])$. Plants were fertilized weekly with a $0.1 \%$ solution of 14-10-14 (N-P-K) with micronutrients. Trees were pruned completely to force growth of new shoots and were exposed in the experimental orchard when they were about $50 \%$ expanded, so that all the leaves were susceptible to ABS. Trap plants were $1.5 \mathrm{~m}$ tall when deployed in the field, with about 100 susceptible leaves each. Exposed trap plants were returned to a growth chamber (approximately $23^{\circ} \mathrm{C}$ ) and disease severity was evaluated on alternating days for 1 week on all leaves using the following severity rating scale: $0=$ no lesions, $1=1$ to 2 lesions, $2=3$ to 5 lesions, $3=6$ to 10 lesions, $4=11$ to 15 lesions, and $5=>15$ lesions (23). Due to the coalescence of lesions and necrosis expanding along the veins in some plants, analyses were carried out on disease incidence calculated as the proportion of symptomatic leaves.

Environmental data were monitored hourly in the orchard with an automated meteorological station (Hobo U30; Onset Computer Corp.), including sensors for air temperature and ambient $\mathrm{RH}$ (Hobo S-THB, accuracies $\pm 0.2^{\circ} \mathrm{C}$ and $\pm 2.5 \%$ ), rainfall (7852, resolution $0.2 \mathrm{~mm}$; Davis Instruments Corp.), wetness duration (Hobo S-LWA, resolution 0.59\%), and wind speed (Hobo S-WSA, accuracy $\pm 1.1 \mathrm{~m} / \mathrm{s}$ ). Environmental monitors were located within the row in the experimental area at the site of a missing tree. Data were collected at about $1.5 \mathrm{~m}$ above the soil surface, in the top one-quarter of the canopy height. Leaf wetness sensors were placed with a northerly exposure and fixed at a $30^{\circ}$ angle from the horizontal. For each weekly period, the following environmental variables were calculated: total rainfall amount $(\mathrm{mm})$, number of rain days $(>0.2 \mathrm{~mm})$, number of rain hours $(>0.2 \mathrm{~mm})$, number of wetness periods $(>1 \mathrm{~h})$, total wetness duration $(\mathrm{h})$, average duration of wetness periods (h), maximum duration of wetness periods (h), average temperature $\left({ }^{\circ} \mathrm{C}\right)$, average temperature of wetness periods $\left({ }^{\circ} \mathrm{C}\right)$, average $\mathrm{RH}(\%)$, and average wind speed $(\mathrm{m} / \mathrm{s})$.

Analysis. The R software v.2.15.1 (R Development Core Team) was used in all analyses. Data on inoculum sources and airborne inoculum were analyzed descriptively. The correlation between the number of pathogenic colonies and the total collected with the semiselective medium ARSA was analyzed with the Spearman's rank correlation coefficient. Differences in disease incidence between trap plants of Fortune and Nova during the infection periods in spring, summer, autumn, and winter in each year and the entire 2-year period were analyzed using the $t$ test. Correlations among disease incidence in trap plants and environmental variables were analyzed using the Spearman's rank correlation coefficient.

Binary recursive partitioning was used to construct classification trees for disease presence in trap plants of Fortune and Nova using the tree package for R (29). The goal in tree modeling is to divide the data into subgroups (nodes) that are homogenous; that is, where the response variables have similar values or are members of the same class. This process takes place in three stages: tree grow- 
ing, tree stopping, and tree pruning (10). For each exposure period, disease presence or absence was defined separately for each cultivar based on disease incidence data. The dataset was split into increasingly homogenous subgroups, selecting the explanatory variable and splitting value that maximized the reduction in deviance. An initial tree was grown using the 11 environmental variables described above as predictors. All possible dichotomizations of all variables (above versus below a given threshold) were considered. Using each possible dichotomization, all the possible ways of partitioning the sample into two distinct subsets were considered. The default stopping criteria in the tree package were used (i.e., the smallest permitted node size was 10 , and a node was not partitioned subsequently if the within-node deviance was less than 0.01 of that of the root node). Once the initial tree had been grown, the tree was pruned to the optimal number of nodes to minimize the deviance, but keeping only those with more than $10 \%$ of the total deviance.

Generalized linear models (GLMs) were used to analyze potential relationships between disease incidence in trap plants and environmental variables. However, due to the large proportion of zero values of disease incidence, intractable problems of overdispersion were detected using different probability distributions, including Poisson and negative binomial, and even applying zero-inflated models (22). In contrast to GLMs, which estimate functions through the center of data distributions (expected values), with quantile regression, it is possible to obtain a range of estimates considering different portions of data distributions (quantiles). The $\tau$ th quantile $(0 \leq \tau \leq 1)$ of a random variable $Y$ is the inverse cumulative distribution function, $F^{-1}(\tau)$, which is defined as the smallest real value $y$ such that the probability of obtaining smaller values of $Y$ is greater than $\tau$. The one-sample quantile definition is extended to the linear model

$$
y=X \beta+v(X) e
$$

by defining the $\tau$ th regression quantile as

$$
\begin{gathered}
Q_{Y}(\tau \mid X)=X \beta(\tau) \\
\beta(\tau)=\beta+v(\bullet) F_{e}^{-1}(\tau)
\end{gathered}
$$

where $y$ is an $n \times 1$ vector of dependent responses; $\beta$ is a $p \times 1$ vector of unknown regression parameters which, in this present case, are the intercept $\left(\beta_{0}\right)$ and the slope $\left(\beta_{1}\right) ; X$ is an $n \times p$ matrix of predictors (first column consist of $1 \mathrm{~s}$ ); $v(\bullet)>0$ is some known function; and $e$ is an $n \times 1$ vector of random errors $(5,19)$. Quantile regression was used to estimate the effects of environmental variables in disease incidence using the quantreg package for $\mathrm{R}$ (18). The quantiles of disease incidence in Fortune and Nova from $\tau=$

Table 1. Isolation frequency of Alternaria from samples of plant material collected in the experimental orchard during 2011 and 2012

\begin{tabular}{llcc}
\hline & & \multicolumn{2}{c}{ Isolation of Alternaria $(\boldsymbol{\%})^{\mathbf{a}}$} \\
\cline { 3 - 4 } Plants & Material & Total & Pathogenic \\
\hline Citrus reticulata & Dry twigs & $79.4 \pm 6.9$ & $29.7 \pm 5.2$ \\
& Green twigs & $100.0 \pm 0.0$ & $1.1 \pm 0.2$ \\
& Fruit & $35.7 \pm 0.3$ & $23.8 \pm 2.4$ \\
& Leaves & $100.0 \pm 00.0$ & $95.0 \pm 1.1$ \\
& Leaf litter & $75.4 \pm 8.5$ & $2.7 \pm 0.8$ \\
Weeds & & & \\
Araujia sericifera & Fresh leaves & $28.6 \pm 3.3$ & $\ldots$ \\
Bromus diandrus & Fresh leaves & $66.7 \pm 7.1$ & $\ldots$ \\
Chrysanthemum spp. & Fresh leaves & $14.3 \pm 2.1$ & $\ldots$ \\
Convolvulus arvensis & Fresh leaves & $69.0 \pm 7.5$ & $\ldots$ \\
Conyza spp. & Dry leaves & $58.4 \pm 8.9$ & $\ldots$ \\
& Fresh leaves & $39.7 \pm 6.5$ & $\ldots$ \\
Cyperus rotundus & Fresh leaves & $4.8 \pm 0.6$ & $\ldots$ \\
Diplotaxis erucoides & Dry leaves & $76.2 \pm 3.4$ & $\ldots$ \\
Oxalis pes-caprae & Fresh leaves & $19.0 \pm 1.7$ & $\ldots$ \\
Senecio vulgaris & Fresh leaves & $85.7 \pm 3.5$ & $\ldots$ \\
Sonchus spp. & Dry leaves & $26.2 \pm 4.5$ & $2.3 \pm 0.5$ \\
& Fresh leaves & $29.8 \pm 2.1$ & $9.5 \pm 1.1$ \\
\hline
\end{tabular}

\footnotetext{
a Ten samples of 15 isolation points for each plant material.
}

0.10 to $\tau=0.90$ by 0.005 increments were analyzed against each of the 11 environmental variables described above. The default method was used to compute the fit using the modified version of the Barrodale and Roberts algorithm and the confidence intervals for the estimated parameters based on inversion of a rank test (18).

\section{Results}

Inoculum sources. Isolates of Alternaria were recovered from all the mandarin tissues analyzed, with percentages ranging from $35.7 \%$ in fruit lesions to $100 \%$ in lesions in green leaves and twigs (Table 1). Pathogenic strains of A. alternata were isolated from all
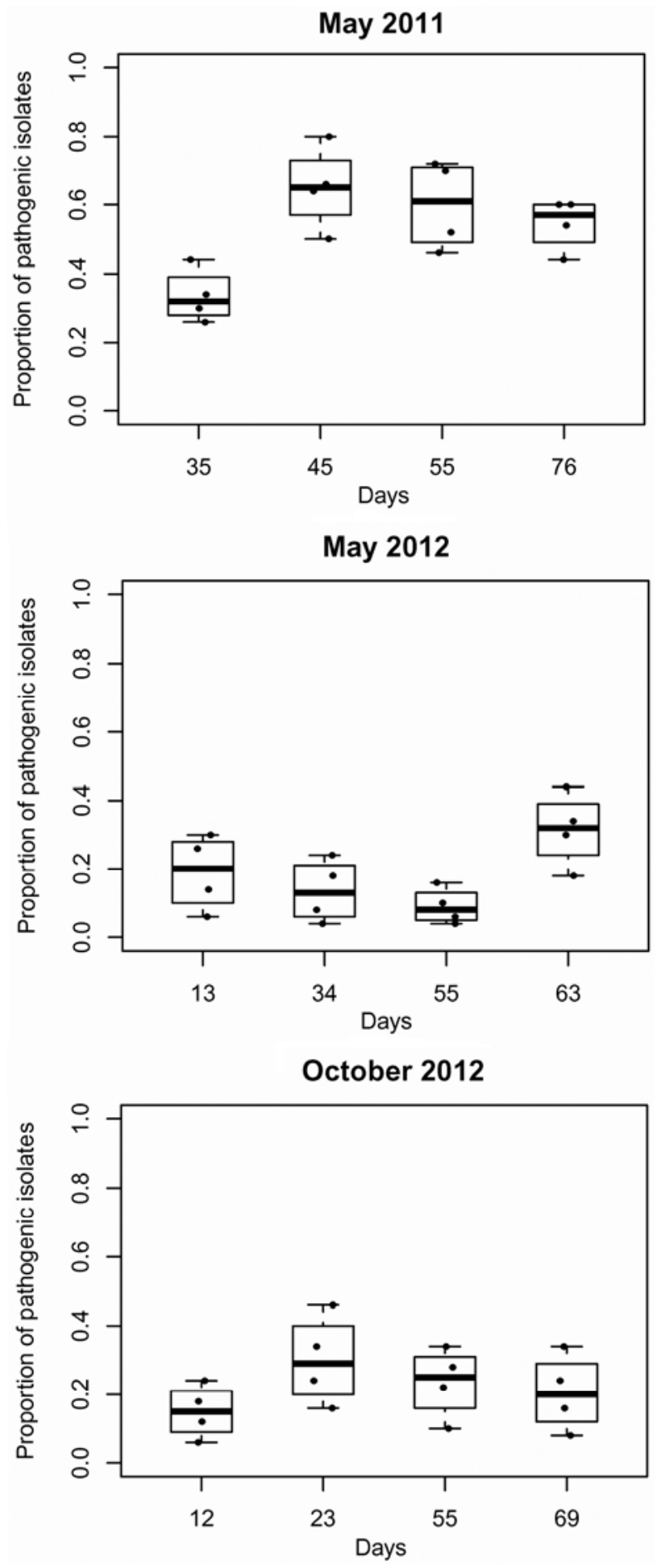

Fig. 1. Proportion of pathogenic colonies of Alternaria alternata isolated from fallen young mandarin leaves affected by Alternaria brown spot in three experiments conducted in 2011 and 2012, showing box-whisker plots for each sampling date after leaf drop $(n=50)$. 
the mandarin tissues analyzed, with a proportion ranging from $1.1 \%$ in green twigs to $95 \%$ in green leaves. Alternaria spp. were isolated from all the weeds collected, ranging from $4.8 \%$ in fresh leaves of $C$. rotundus to $85.7 \%$ in fresh leaves of $S$. vulgaris. Pathogenic strains of A. alternata were isolated only from dry and fresh leaves of Sonchus spp. in proportions ranging from 2.3 to $9.5 \%$.

Pathogenic isolates of A. alternata were detected in ABSaffected young fallen leaves in all experiments and sampling dates (Fig. 1). The proportion of pathogenic isolates was 26 to $80 \%$ in May 2011, 4 to 44\% in May 2012, and 6 to 46\% in October 2012. Leaves were completely decomposed after 76 days in May 2011, 63 days in May 2012, and 69 days in October 2012.

Airborne inoculum. Conidia of Alternaria spp. were detected continuously in the spore trap in 2011 and 2012 (Fig. 2). Counts were 0.8 to 30.5 conidia $/ \mathrm{cm}^{2}$, with an average of 10.62 , in 2011 ; and 0.8 to 34.4 , with an average of 5.8, in 2012. In total, 1,049 colonies of Alternaria were collected in the experimental orchard by exposing ARSA plates to air in 31 days during 2011 and 2012

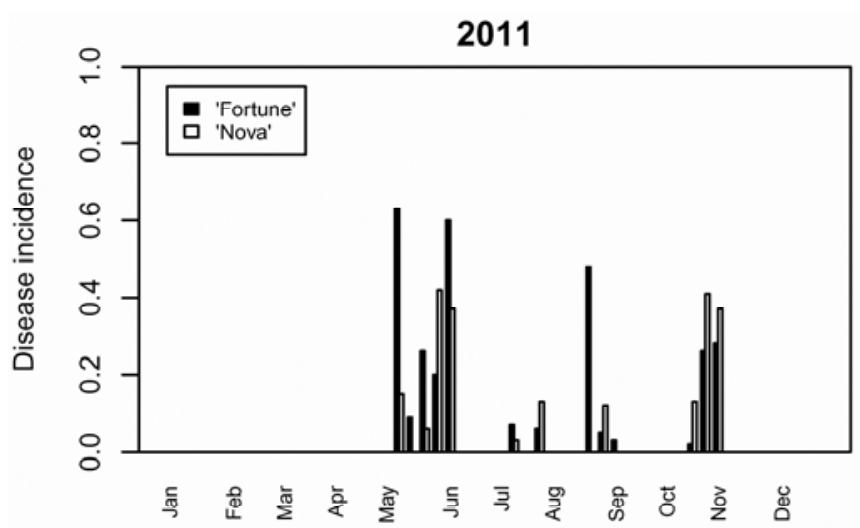

2011

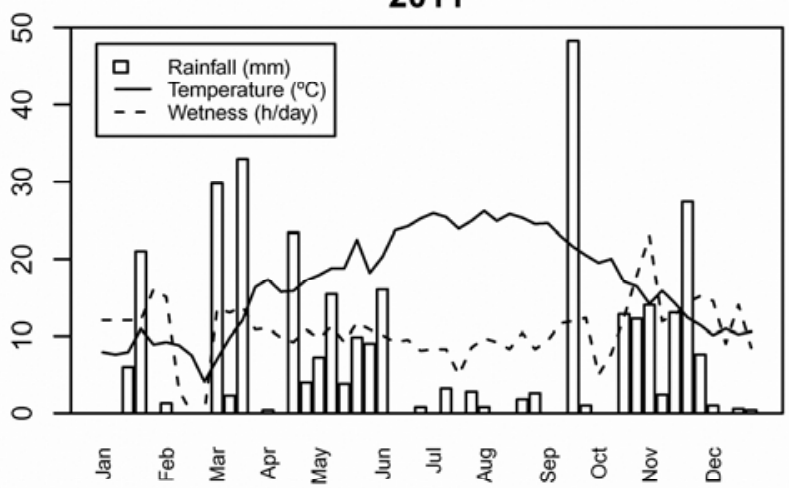

2011

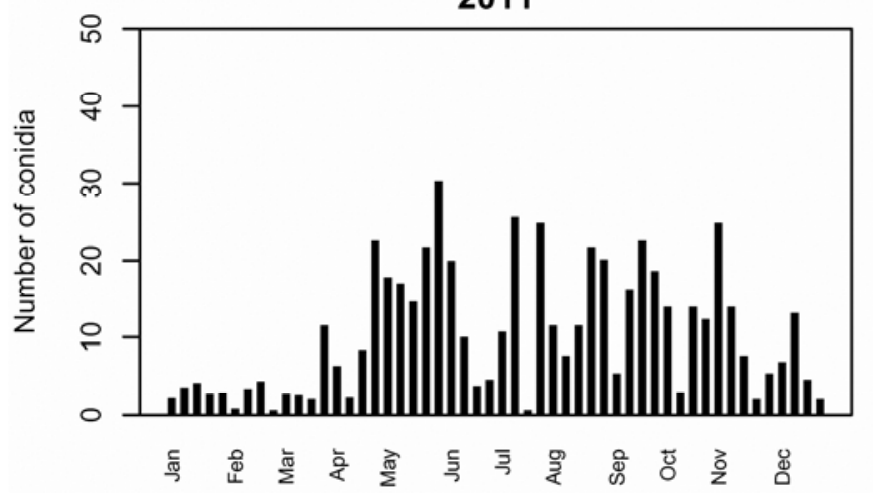

(Fig. 3). When inoculated, 240 colonies of the total collected were pathogenic to Fortune mandarin leaves. The number of pathogenic colonies per sampling date was 1 to 23 , with an average of 7.74 , and the number of nonpathogenic colonies was 1 to 58 , with an average of 26.1. The average proportion of pathogenic colonies was $27.3 \%$ (1.8 to $87.5 \%$ ). No significant correlation was found between the number of pathogenic colonies and the total collected $(P=0.4581)$.

Infection periods. Disease symptoms were observed on trap plants on 22 and 17 of the 104 deployment periods for Fortune and Nova, respectively (Fig. 2). In spring 2011, five infection periods were observed in trap plants of Fortune and four infection periods in Nova. Disease incidence was 0.35 (0.09 to 0.63) in Fortune and 0.25 (0.06 to 0.42 ) in Nova. In spring 2012, only one infection period was observed in both cultivars. Summer infections were observed only in 2011. Five infection periods were detected in Fortune, with a disease incidence of 0.13 (0.03 to 0.48), and three infection periods in Nova, with a disease incidence of 0.09 (0.03 to
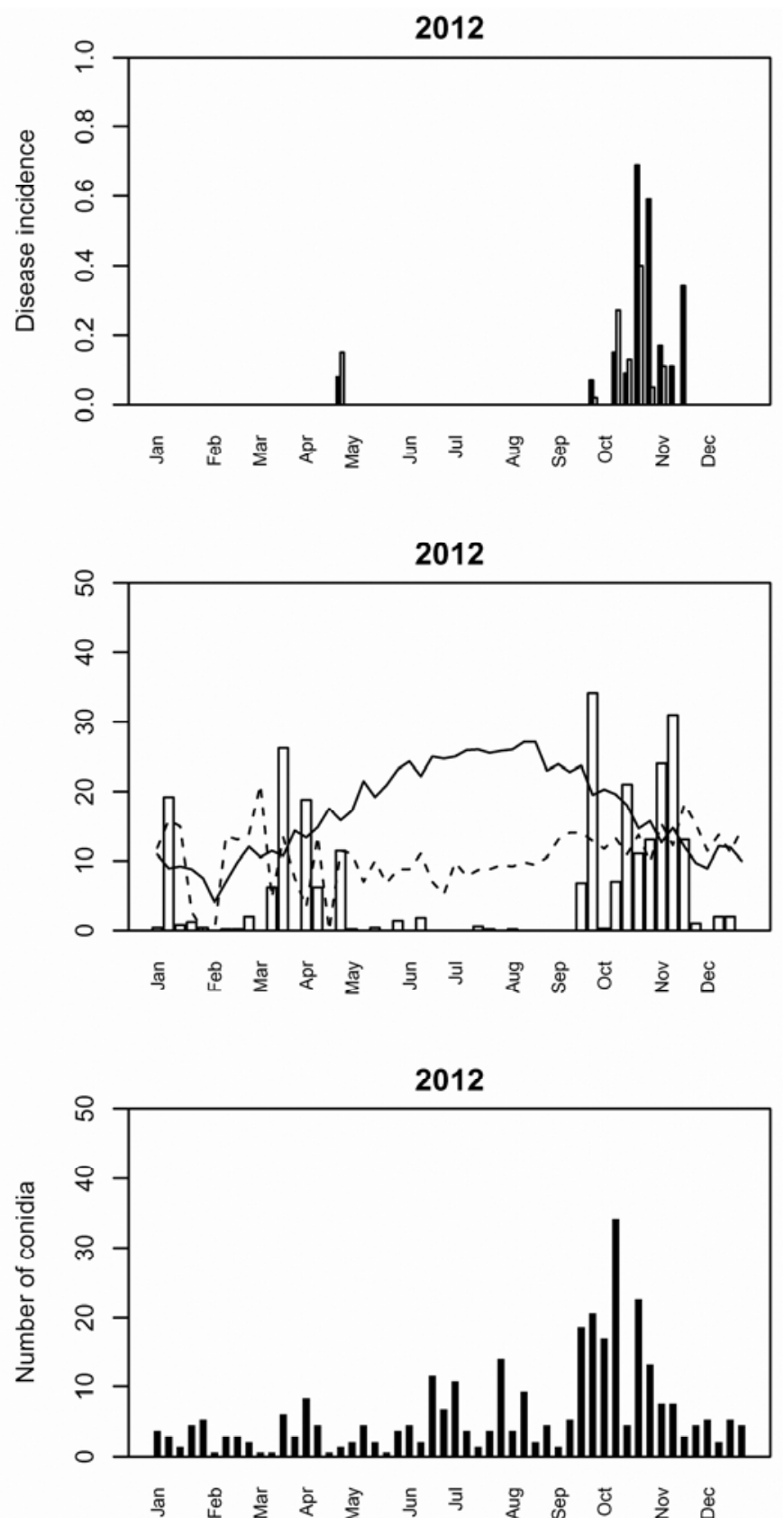

Fig. 2. Weekly values of disease incidence in trap plants of 'Fortune' and 'Nova' mandarin, number of Alternaria conidia detected in the spore trap, rainfall, average temperature, and average wetness duration in 2011 and 2012. 
0.13). Autumn infections were observed in both years. Three periods were detected in 2011, with a disease incidence of 0.18 (0.02 to 0.28$)$ in Fortune and 0.30 (0.13 to 0.41$)$ in Nova. In autumn 2012, eight periods were detected in Fortune, with a disease incidence of 0.27 ( 0.07 to 0.69 ), and six periods in Nova, with a disease incidence of 0.16 (0.02 to 0.40$)$. No significant differences in disease incidence were detected between Fortune and Nova during the infection periods in spring $2011(P=0.4716)$, summer $2011(P=0.6460)$, autumn $2011(P=0.3894)$, autumn $2012(P=0.2980)$, and the entire period of study $(P=0.4289)$.

In total, $335.2 \mathrm{~mm}$ of rainfall and 100 rain days were recorded in 2011 and $264.3 \mathrm{~mm}$ and 86 rain days in 2012. Rainfall in spring and autumn represented $78.1 \%$ of the total in 2011 and $85.4 \%$ in 2012 (Fig. 2). Average temperatures in 2011 and 2012 were $8.4 \pm$ 1.8 and $9.1 \pm 2.1^{\circ} \mathrm{C}$ in winter, $18.1 \pm 3.1$ and $18.5 \pm 4.4^{\circ} \mathrm{C}$ in spring, $24.9 \pm 0.8$ and $25.1 \pm 1.4^{\circ} \mathrm{C}$ in summer, and $15.6 \pm 3.8$ and $14.5 \pm 3.8^{\circ} \mathrm{C}$ in autumn. Total wetness duration per week ranged from $36.6 \pm 24.1 \mathrm{~h}$ in summer 2012 to $78.3 \pm 30.1 \mathrm{~h}$ in autumn 2011. Relative humidity ranged from $66.6 \pm 7.4 \%$ in spring 2012 to $81.1 \pm 8.3 \%$ in autumn 2011 . Wind speed ranged from $0.23 \pm$ $0.05 \mathrm{~m} / \mathrm{s}$ in summer 2011 to $0.69 \pm 0.53 \mathrm{~m} / \mathrm{s}$ in winter 2012 .

A positive correlation of total rainfall amount, number of rain days, and number of rain hours with ABS incidence in trap plants was observed in both cultivars (Table 2). Disease incidence was positively correlated with total wetness duration, maximum wetness duration, and average relative humidity. Average temperature of wetness periods was positively correlated with ABS incidence only in Fortune. Average wind speed was negatively correlated with disease incidence in both cultivars. Average temperature, average duration of wetness periods, and number of wetness periods were not correlated with ABS incidence. All four wetness variables

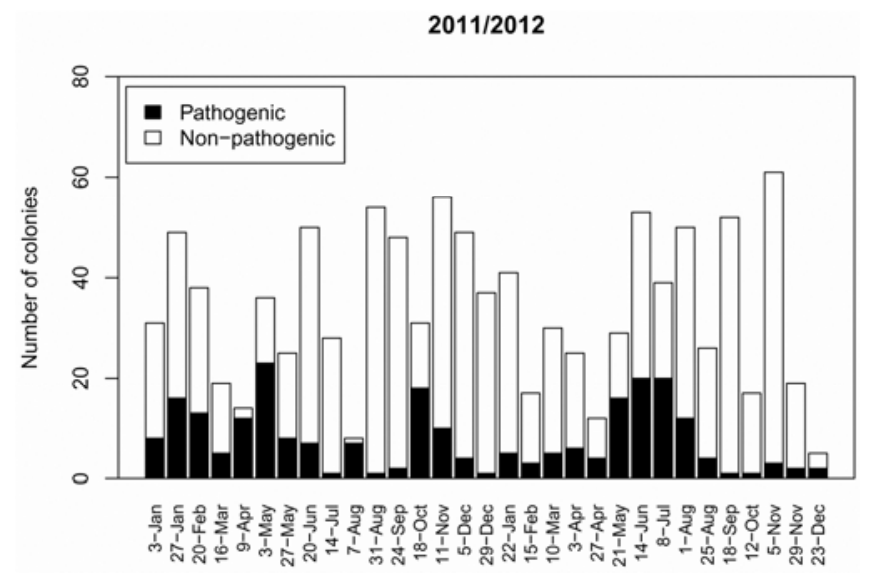

Fig. 3. Number of pathogenic and nonpathogenic colonies of Alternaria collected by exposing plates of the semiselective medium ARSA to air in the experimental orchard in 31 days in 2011 and 2012. studied were positively correlated with total rainfall, number of rain days, number of rain hours, and average $\mathrm{RH}$ (Table 2). All three rainfall variables were positively correlated among them. The four wetness variables were also significantly correlated among them, except between average duration of wetness periods and number of wetness periods.

The generated tree models between disease presence in trap plants of Fortune and Nova and the environmental variables with 104 weekly periods are shown in Figure 4 . In both cultivars, total rainfall amount and average temperature were the variables finally selected, resulting in three terminal nodes. Total rainfall amount was the environmental variable with the greatest discriminative power in both cases. The splitting criteria (thresholds) were 2.55 $\mathrm{mm}$ of rainfall and $12.47^{\circ} \mathrm{C}$ of average temperature. The residual mean deviance was $0.5588(56.44 / 101)$ in Fortune and 0.3524 $(35.59 / 101)$ in Nova. The misclassification error rate was 0.1058 $(11 / 104)$ in Fortune and 0.0961 (10/104) in Nova. Sensitivity was $86.36 \%$ in Fortune and $100 \%$ in Nova. Specificity was $90.24 \%$ in Fortune and $88.5 \%$ in Nova. In the case of Fortune, the terminal node included 19 infection periods and 8 periods without infection. Three infection periods were not included in this node, corresponding to the following values of rainfall and temperature: $1.8 \mathrm{~mm}$ and $25.3^{\circ} \mathrm{C}, 0 \mathrm{~mm}$ and $24.6^{\circ} \mathrm{C}$, and $13 \mathrm{~mm}$ and $12^{\circ} \mathrm{C}$. In the case of Nova, the terminal node included 17 infection periods and 10 periods without infection. All infection periods were included in this node.

Total rainfall amount, number of rain days, and total wetness duration were the only environmental variables showing a significant relationship with disease incidence in trap plants of Fortune and Nova (Fig. 5). Due to the great number of zeroes, this significant relationship was detected only in the upper quantiles of disease incidence: rainfall $(0.80 \leq \tau \leq 0.90)$, rain days $(0.80 \leq \tau \leq 0.90)$, and total wetness $(0.85 \leq \tau \leq 0.90)$. Estimates and $95 \%$ confidence intervals for the slope $\left(\widehat{\beta}_{1}\right)$ of rainfall were 0.0214 (0.0070 to $0.0360)$ to $0.0375(0.0215$ to 0.0547$)$ in Fortune and 0.0097 (0.0052 to 0.0271$)$ to $0.0264(0.0108$ to 0.0464$)$ in Nova. In the case of rain days, $\widehat{\beta}_{1}$ was $0.0433(0.0235$ to 0.0582$)$ to 0.0680 (0.0419 to 0.1691$)$ in Fortune and 0.0325 (0.0184 to 0.0612) to 0.0683 (0.0621 to 0.0994$)$ in Nova. Values of $\widehat{\beta}_{1}$ of wetness were 0.0022 (0.0015 to 0.0026$)$ to $0.0031(0.0025$ to 0.0034$)$ in Fortune and 0.0015 (0.0011 to 0.0032$)$ to $0.0029(0.0018$ to 0.0039$)$ in Nova.

\section{Discussion}

Pathogenic isolates of A. alternata were found in all affected plant tissue in the canopy as well as in the leaf litter, confirming previous studies from Florida, which indicated that inoculum is broadly distributed in affected orchards (28). Pathogenic strains of A. alternata were also detected in fresh and dry leaves of weeds belonging to the genus Sonchus. Although some references are available for other Alternaria spp. (30), overseasoning in wild plants has not been previously reported for the ABS pathogen.

Table 2. Spearman's rank correlation coefficients between incidence of Alternaria brown spot in trap plants of 'Fortune' and 'Nova' and environmental variables ${ }^{\mathrm{a}}$

\begin{tabular}{|c|c|c|c|c|c|c|c|c|c|c|c|c|}
\hline Variables $^{\mathbf{b}}$ & $\begin{array}{c}\text { Fortune } \\
\text { DI }^{c}\end{array}$ & $\begin{array}{l}\text { Nova } \\
\text { DIc }\end{array}$ & $\begin{array}{c}\text { Wetness } \\
\text { (avg temp) }\end{array}$ & $\begin{array}{l}\text { Wetness } \\
(\max )\end{array}$ & $\begin{array}{c}\text { Wetness } \\
\text { (no periods) }\end{array}$ & $\begin{array}{l}\text { Wetness } \\
\text { (avg) }\end{array}$ & $\begin{array}{c}\text { Wetness } \\
\text { (total) }\end{array}$ & $\begin{array}{l}\text { Wind } \\
\text { speed }\end{array}$ & $\begin{array}{l}\text { Relative } \\
\text { humidity }\end{array}$ & Temp & $\begin{array}{l}\text { Rain } \\
\text { hours }\end{array}$ & $\begin{array}{l}\text { Rain } \\
\text { days }\end{array}$ \\
\hline Rainfall & $0.55 * *$ & $0.52 * *$ & 0.03 & $0.64 * *$ & $0.41 * *$ & $0.41 * *$ & $0.58 * *$ & -0.11 & $0.58 * *$ & -0.15 & $0.97 * *$ & $0.91 * *$ \\
\hline Rain days & $0.42 * *$ & $0.36^{* *}$ & 0.1 & $0.66^{* *}$ & $0.49 * *$ & $0.46 * *$ & $0.67 * *$ & -0.08 & $0.64 * *$ & $-0.23 *$ & $0.96 * *$ & $\ldots$ \\
\hline Rain hours & $0.52 * *$ & $0.48 * *$ & 0.03 & $0.64 * *$ & $0.43 * *$ & $0.40 * *$ & $0.61 * *$ & -0.10 & $0.59 * *$ & -0.18 & $\ldots$ & $\ldots$ \\
\hline Temperature & 0.13 & 0.11 & $0.84 * *$ & $-0.41 * *$ & 0.06 & $-0.36 * *$ & -0.14 & $-0.38 * *$ & 0.07 & $\ldots$ & $\ldots$ & $\ldots$ \\
\hline Relative humidity & $0.31 * *$ & $0.26^{* *}$ & $0.45 * *$ & $0.60 * *$ & $0.80 * *$ & $0.41 * *$ & $0.86 * *$ & $-0.34 * *$ & $\ldots$ & $\ldots$ & $\ldots$ & $\ldots$ \\
\hline Wind speed & $-0.32 * *$ & $-0.27 * *$ & $-0.53 * *$ & -0.02 & $-0.31 * *$ & -0.08 & $-0.26 * *$ & $\ldots$ & $\ldots$ & $\ldots$ & $\ldots$ & $\ldots$ \\
\hline Wetness (total) & $0.26^{* *}$ & $0.23 *$ & $0.26 * *$ & $0.71 * *$ & $0.81 * *$ & $0.59 * *$ & $\ldots$ & $\ldots$ & $\ldots$ & $\ldots$ & $\ldots$ & $\ldots$ \\
\hline Wetness (avg) & 0.17 & 0.15 & -0.15 & $0.61 * *$ & 0.15 & $\ldots$ & $\ldots$ & $\ldots$ & $\ldots$ & $\ldots$ & $\ldots$ & $\ldots$ \\
\hline Wetness (no periods) & 0.12 & 0.10 & $0.39^{* *}$ & $0.49 * *$ & $\ldots$ & $\ldots$ & $\ldots$ & $\ldots$ & $\ldots$ & $\ldots$ & $\cdots$ & $\ldots$ \\
\hline Wetness (max) & $0.25^{*}$ & $0.24 *$ & -0.18 & $\ldots$ & $\ldots$ & $\ldots$ & $\ldots$ & $\ldots$ & $\ldots$ & $\ldots$ & $\ldots$ & $\ldots$ \\
\hline Wetness (avg temp) & $0.22 *$ & 0.18 & $\ldots$ & $\ldots$ & $\ldots$ & $\ldots$ & $\ldots$ & $\ldots$ & $\ldots$ & $\ldots$ & $\ldots$ & $\ldots$ \\
\hline
\end{tabular}

a Asterisks: ** and * indicate significant at $P<0.01$ and 0.05 , respectively.

${ }^{\mathrm{b}}$ In total, 104 weekly periods from January 2011 to December 2012 . Total amount of rainfall (mm), rain days ( $\left.>0.2 \mathrm{~mm}\right)$, rain hours ( $\left.>0.2 \mathrm{~mm}\right)$, total wetness duration (h), number of wetness periods $\left(>1 \mathrm{~h}\right.$ ), average (avg) temperature (temp) $\left({ }^{\circ} \mathrm{C}\right)$, avg relative humidity $(\%)$, avg wind speed (m/s), avg wetness duration $(\mathrm{h})$, avg temp of wetness periods $\left({ }^{\circ} \mathrm{C}\right)$, and maximum (max) wetness duration $(\mathrm{h})$.

${ }^{c}$ Disease incidence $(\mathrm{DI})=$ proportion of affected leaves. 
Nevertheless, A. alternata is considered a polyphagous necrotroph that can easily colonize and reproduce in decaying plant tissues such as dead weeds and plant debris (30). Although with different proportions, pathogenic and nonpathogenic strains coexisted in all plant materials analyzed. Some studies suggested that these coinfections facilitate the transfer of pathogenicity determinants between strains of A. alternata (36).

The pathogen survived in symptomatic immature leaves fallen on the orchard floor during the whole period of study (63 to 76 days), when young leaves were completely decayed. Hence, survival of the ABS pathogen in plant debris seems to be conditioned by survival of the debris itself. In Florida, sporulation of the pathogen on mature leaves of tangelo 'Minneola' was virtually zero after 12 days on the soil surface (28). Considering that litter decomposition rates increase with temperature and precipitation (44), the survival of the pathogen in diseased mature leaves under semi-arid conditions is expected to be longer than in the humid climate in Florida. Considering the broad distribution and longevity of the pathogen in affected orchards, practical implementation of inoculum reduction measures seems not to be feasible.

Conidia of Alternaria spp. were captured continuously in the spore trap during the 2-year period. However, from the 1,049 colonies of Alternaria isolated in the ARSA plates, only an average of
$22.8 \%$ were pathogenic and identified as the ABS pathogen. This is in contrast with the $99.6 \%$ of pathogenic colonies reported in previous studies conducted in Florida with the same methodology (35). Furthermore, the number of pathogenic isolates was not significantly correlated with the total captured. Thus, in our conditions, quantifying airborne populations of Alternaria conidia without discriminating between pathogenic and nonpathogenic isolates is not an adequate technique for airborne inoculum monitoring. Although more efficient spore trapping devices than the one used in this study are available, they are also based on spore morphology, which is not sufficient to distinguish the pathogen from the saprophytic strains (36). Spore traps that implement DNA-based methods are generally required for pathogen identification at intraspecific level (16). In the case of A. alternata, the biosynthetic genes of the ACT-toxin have been characterized (36) but validated molecular methods to detect the toxin-producing strains are not currently available. Thus, pathogen identification is still based mainly on pathogenicity tests.

The limitations indicated above constrained a comprehensive statistical analysis of inoculum dynamics and their potential relationships with environmental variables and infections of trap plants. Nevertheless, pathogenic isolates of A. alternata were detected in all of the 31 periods evaluated during two consecutive
'Fortune'

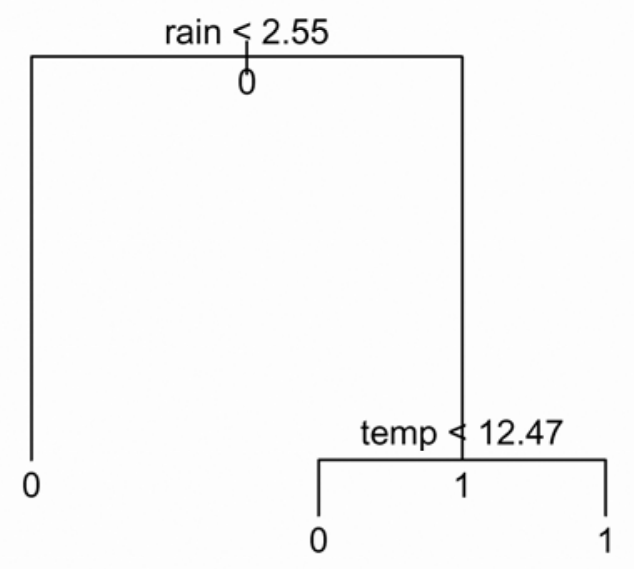

'Fortune'

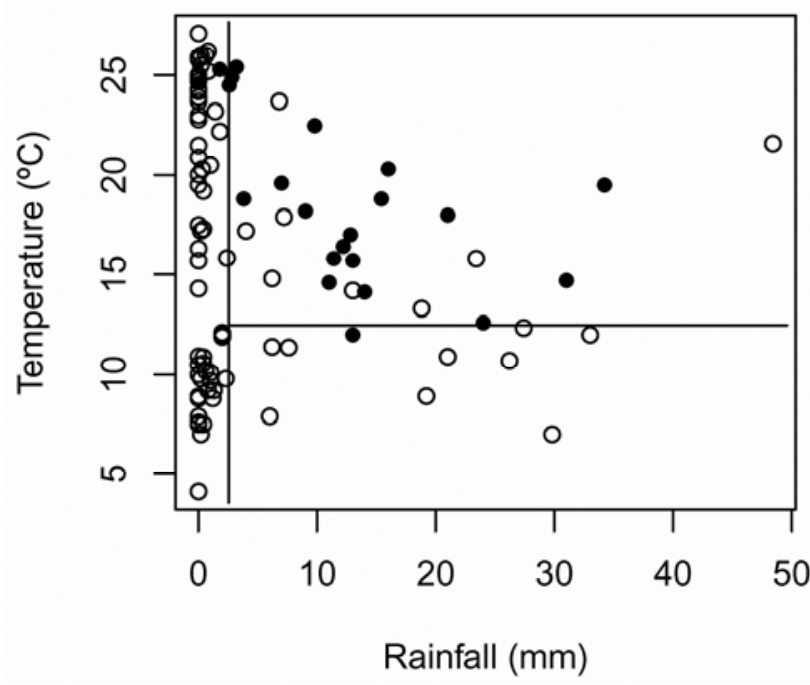

'Nova'

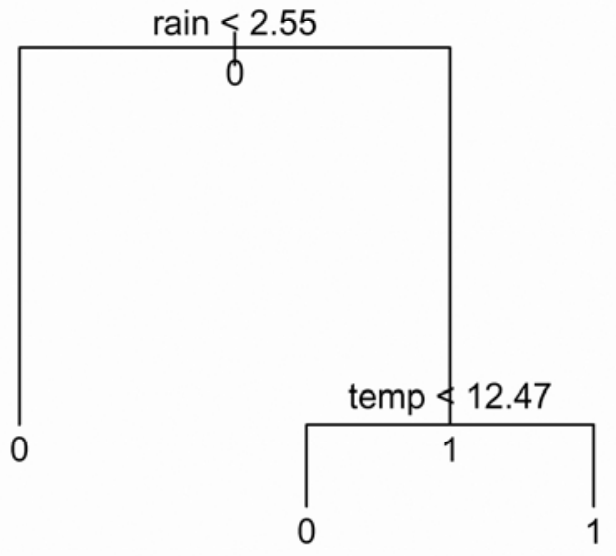

'Nova'

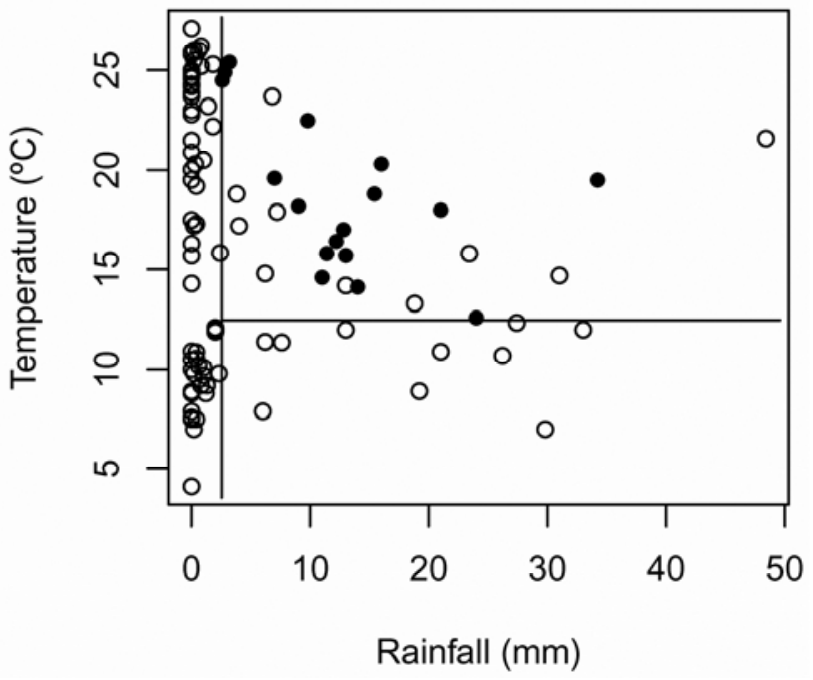

Fig. 4. Tree models (top) and partition plots (bottom) for a classification of disease presence (1) or absence (0) in trap plants of 'Fortune' and 'Nova' based on rainfall amount and average temperature, displaying at each node the splitting criteria and the majority class fitted by the models. Black dots indicate infection periods and open circles periods without infection. 
years, indicating that overall host and environmental conditions were not limiting for conidial production, release, and dissemination. This is in agreement with previous studies from Florida showing that inoculum was broadly distributed through the growing season and was not a limiting factor for infection $(28,33,35)$. Experiments conducted under controlled conditions demonstrated that conidia of A. alternata are released by abrupt changes in $\mathrm{RH}$ or

\section{'Fortune'/rainfall}

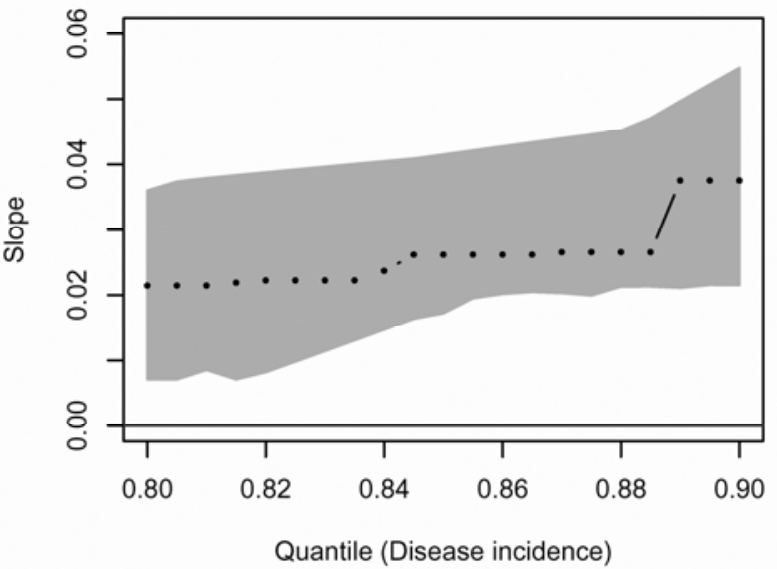

'Fortune'/rain days

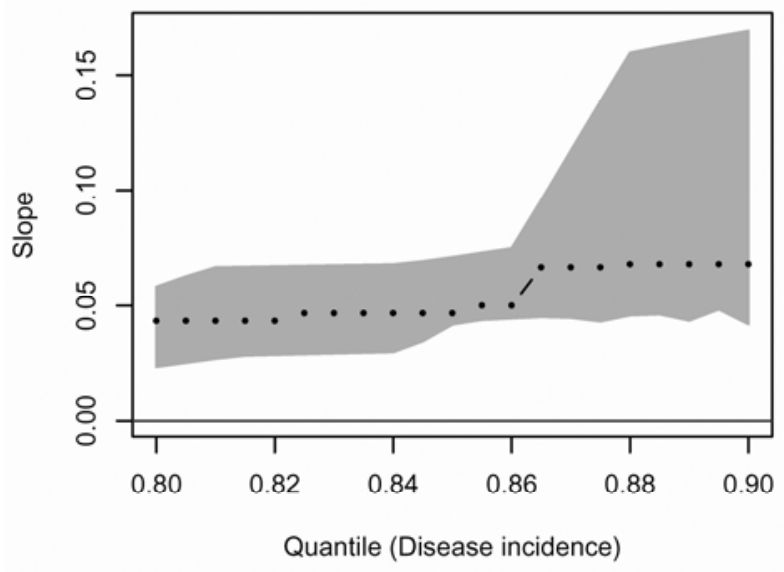

'Fortune'/wetness

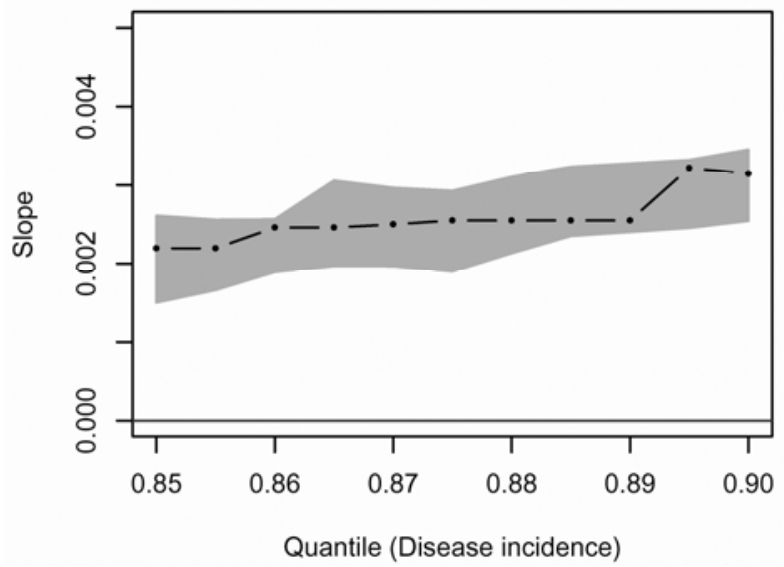

rainfall events (35). The presence of conidia during both the rainy and rainless periods indicates that these two mechanisms also could play a significant role for conidial release under semi-arid conditions.

In 2011, infections were distributed mainly in spring and autumn, with some infections also in summer. However, in 2012, infections were concentrated almost exclusively in autumn, with
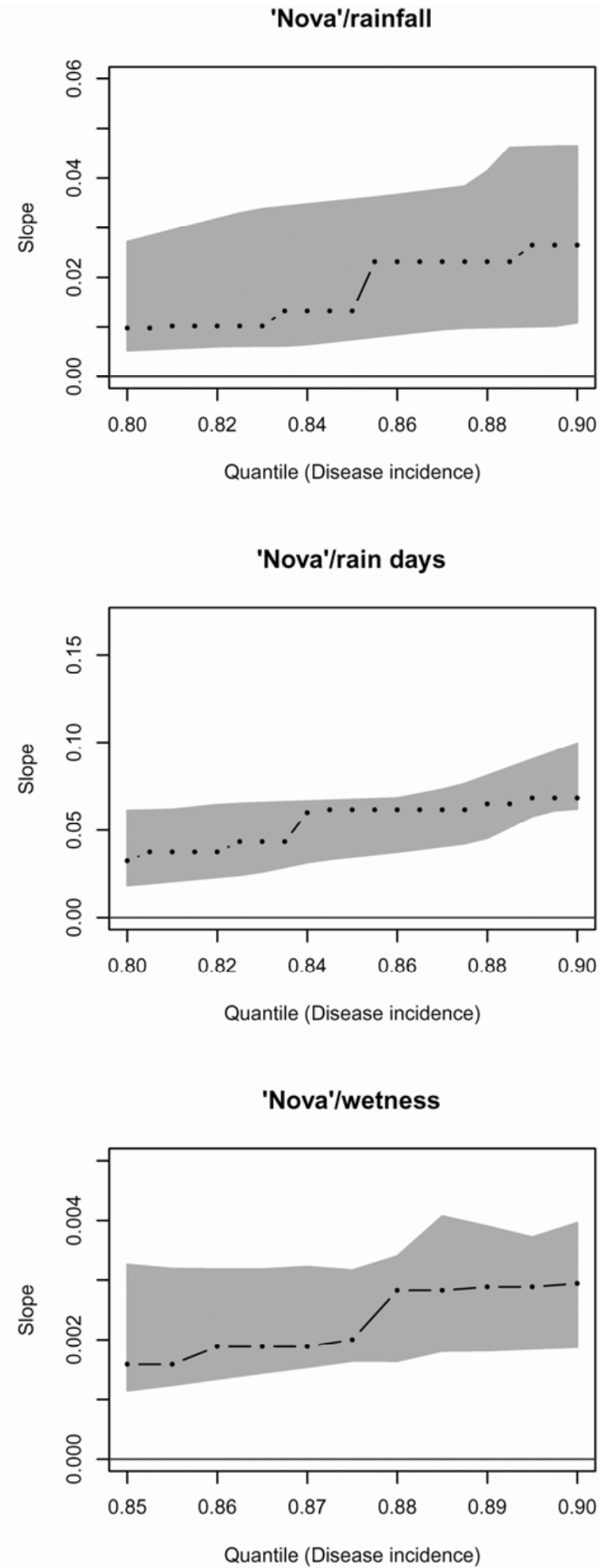

Fig. 5. Estimates of the slope $\left(\widehat{\beta}_{1}\right)$ for regression quantiles relating disease incidence in trap plants of 'Fortune' and 'Nova' to total rainfall amount (mm), number of rain days, and total wetness duration (h) during exposure periods. Dotted line is the step function of sample estimates by quantiles and shaded areas are $95 \%$ confidence intervals from inverting a quantile rank score test by 0.005 increments. 
only one infection period in spring. This is in contrast with the scenario described in the humid areas in Florida, where trap plants became infected all year round and summer was considered the critical period for infection $(33,35)$. A shift in the infection period has been also described for Mycosphaerella nawae, the causal agent of circular leaf spot of persimmon, a pathogen that was previously confined to humid regions in Asia and recently adapted to develop epidemics in semi-arid areas in Spain (41). Leaves are susceptible to the disease until they are fully expanded and hardened $(34,38)$. Under Mediterranean conditions, citrus produces about $80 \%$ of new shoots in the spring flush (11). Consequently, infections of A. alternata from April to June cause severe lesions on leaves, defoliation, and abscission of young fruit. In autumn, the fruit is still susceptible (40) and lesions caused by infections from September to November markedly reduce the commercial quality of the fruit for the fresh market.

Tree models were used to explore the relationships between the presence of infections and environmental variables for 2 years. Classification and regression tree analysis is widely used in many research areas (14), and some applications in plant disease epidemiology are also available $(1,13,24)$. These models do not make a priori hypotheses on the distribution of the data and are able to detect interactions among variables which are usually missed by other statistical methods. However, because they are very datadriven, trees are considered to be unstable; therefore, different data sets can yield different selections of variables and thresholds (10).

After evaluating all the possible splits with all environmental variables, tree models indicated that almost all infections occurred on weeks with rainfall $\geq 2.5 \mathrm{~mm}$ and average temperature $\geq 12.5^{\circ} \mathrm{C}$. The rainfall threshold resulted in a much higher explained deviance than the temperature. In fact, only one infection period was observed in the absence of rain but resulted in a disease incidence of just 3\% of leaves affected. Interestingly, this rainfall threshold obtained by recursive partitioning was the same defined in the ALTER-RATER model for ABS in Florida (33), the FAST model for tomato early blight in Pennsylvania (20), as well as other forecasting systems developed for leaf spot of peanut in Alabama (8), pecan scab in Oklahoma (25), and grapevine downy mildew in New York (17).

Laboratory studies indicated an optimum temperature for infection of about $27^{\circ} \mathrm{C}$ in Florida and between 22 and $25^{\circ} \mathrm{C}$ in Israel $(7,32)$. In general, species of Alternaria have an optimum for infection above $25^{\circ} \mathrm{C}$ but they are also highly efficient infecting at suboptimal temperatures (30). This seems to be the case in our study, because the vast majority of infections occurred in weeks with average temperatures between 15 and $25^{\circ} \mathrm{C}$, inducing disease incidences sometimes higher that $60 \%$ of leaves affected.

The dataset contained more zeroes than might be predicted from standard error models used with GLMs. Thus, the relationships between disease incidence in trap plants and environmental variables were analyzed by regression quantiles. The statistical theory of regression quantiles was first developed in econometrics (19) and is extensively used in different areas of ecology (4,5). Despite its potential, no references in plant disease epidemiology have been found. Regression quantiles are particularly suited when rates of change of interest are associated with the boundaries of the data distribution. In these cases, it is possible for change in the center of distributions to be statistically indistinguishable from zero even when estimated changes near the extremes of distributions are nonzero. Regression quantiles models can accommodate a relative wide range of data distributions and deal with datasets having a large proportion of zero values (37), which are common in epidemiological studies conducted in semi-arid areas.

A significant positive relationship was found between disease incidence in trap plants and total rainfall amount, number of rain days, and total wetness duration but only in the upper quantiles ( 0.8 to 0.9$)$, where most of the non-zero disease incidence data were situated. Change in quantiles near the maximum response is frequently associated with the presence of limiting factors $(4,5)$, as the rainfall and temperature thresholds indicated above. A plausible interpretation of these results is that the amount of rainfall, number of rain days, and wetness duration are important factors increasing ABS incidence but only when infections are already present.

In Florida, where trap plants were infected almost any time of the year, disease severity was related positively to wetness, rainfall, and temperature (33). In our study, temperature was not significantly related to disease incidence in any of the quantiles studies. Apparently, temperatures above $12.5^{\circ} \mathrm{C}$ are not limiting for infection once moisture requirements are met. The effect of rain increasing ABS incidence was expected, because it facilitates epidemics by supplying free moisture for conidial germination on leaves and fruit, decreasing the amount of harmful radiation, and splash dispersing spores $(30,33)$. Species of Alternaria are particularly efficient in using dew for infection due to their ability for withstanding regimes of interrupted wetting periods (30). In fact, dew was suggested as a key environmental factor in ABS epidemics in semiarid areas $(7,33,34)$. However, our results show that virtually no infections occurred in the absence of rain and as little as $2.5 \mathrm{~mm}$ of precipitation was enough for infection in some weeks. Therefore, dew may be considered to be an important epidemiological factor for increasing disease incidence but not for initiating infections, which were largely driven by rain events.

Nevertheless, about one-third of the periods with rainfall $\geq 2.5$ $\mathrm{mm}$ and temperature $\geq 12.5^{\circ} \mathrm{C}$ did not result in infections. This suggests that additional environmental factors, such as prolonged and frequent dews, may contribute to the onset of infections in some situations. This could be elucidated by analyzing a possible interaction between wetness and rainfall by multiple regression. However, large pairwise correlations were detected between all wetness and rain variables, indicating potential problems with multicollinearity. Because higher rainfall amounts were regularly associated with longer wetting periods, the effect of both variables cannot be easily separated. Empirical evidence in Spain indicates that, under the same rainfall regime, well-ventilated orchards tend to have a lower incidence of ABS. In fact, cultural control practices like wider tree spacing, proper row orientation, and pruning are recommended to improve air circulation and reduce wetness duration in orchards.

Despite the extended periods of host susceptibility (40) and inoculum availability, the restricted distribution of infections throughout the growing season and the strong influence of weather factors in disease onset are encouraging features for the development of efficient DSSs for ABS control under Mediterranean conditions. The availability of accurate rain forecasts will be critical to predict the appearance of the disease, leaving enough time to spray the orchards with fungicides.

\section{Acknowledgments}

Research was funded by INIA RTA2010-00105-00-00-FEDER. A. Vicent was supported by DOC-INIA and D. D. M. Bassimba by AECID-Spain and INAGBE-Angola. We thank C. Llacer and A. Rouzier for technical assistance and L. W. Timmer (CREC-IFAS/University of Florida) for reviewing the manuscript.

\section{Literature Cited}

1. Baker, F. A., Verbyla, D. L., Hodges, C. S., and Ross, E. W. 1993. Classification and regression tree analysis for assessing hazard of pine mortality caused by Heterobasidion annosum. Plant Dis. 77:136-139.

2. Bella, P., Guarino, C., La Rosa, R., and Catara, A. 2001. Severe infections of Alternaria spp. on a mandarin hybrid. J. Plant Pathol. 83:231.

3. Bhatia, A., Roberts, P. D., and Timmer, L. W. 2003. Evaluation of the AlterRater model for timing of fungicide applications for control of Alternaria brown spot of citrus. Plant Dis. 87:1089-1093.

4. Cade, B. S., and Noon, B. R. 2003. A gentle introduction to quantile regression for ecologists. Front. Ecol. Environ. 1:412-420.

5. Cade, B. S., Terrell, J. W., and Schroeder, R. L. 1999. Estimating effects of limiting factors with regression quantiles. Ecology 80:311-323.

6. Campbell, C. L., and Madden, L. V. 1990. Introduction to Plant Disease Epidemiology. John Wiley and Sons, New York.

7. Canihos, Y., Peever, T. L., and Timmer, L. W. 1999. Temperature, leaf wetness, and isolate effects on infection of Minneola tangelo leaves by Alternaria sp. Plant Dis. 83:429-433.

8. Davis, D. P., Jacobi, J. C., and Backman, P. A. 1993. Twenty-four hour rainfall, a simple environmental variable for predicting peanut leaf spot epidem- 
ics. Plant Dis. 77:722-725.

9. Elena, K. 2006. Alternaria brown spot of Minneola in Greece; evaluation of citrus species susceptibility. Eur. J. Plant Pathol. 115:259-262.

10. Franklin, J. 2009. Mapping Species Distributions. Spatial Inference and Prediction. Cambridge University Press, New York.

11. García-Marí, F., Granda, C., Zaragoza, S., and Agustí, M. 2002. Impact of Phyllocnistis citrella (Lepidoptera: Gracillariidae) on leaf area development and yield of mature citrus trees in the Mediterranean area. J. Econ. Entomol. 95:966-974.

12. Golmohammadi, M., Andrew, M., Peever, T. L., Peres, N. A., and Timmer, L. W. 2006. Brown spot of tangerine hybrid cultivars Minneola, Page and Fortune caused by Alternaria alternata in Iran. Plant Pathol. 55:578.

13. Guyot, J., Condina, V., Doare, F., Cilas, C., and Sache, I. 2010. Segmentation applied to weather-disease relationships in South American leaf blight of the rubber tree. Eur. J. Plant Pathol. 126:349-362.

14. Hastie, T., Tibshirani, R., and Friedman, J. 2009. The Elements of Statistical Learning: Data Mining, Inference and Prediction. Springer-Verlag, New York.

15. Herrera-Isla, L. 1992. La mancha parda de los cítricos en Cuba. Levante Agríc. 317/318:49-50.

16. Jackson, S. L., and Bayliss, K. L. 2011. Spore traps need improvement to fulfil plant biosecurity requirements. Plant Pathol. 60:801-810.

17. Kennelly, M. M., Gadoury, D. M., Wilcox, W. F., Magarey, P. A., and Seem, R. C. 2007. Primary infection, lesion productivity, and survival of sporangia in the grapevine downy mildew pathogen, Plasmopara viticola. Phytopathology 97:512-522.

18. Koenker, R. 2013. quantreg: quantile regression. R package version 4.98 . http://CRAN.R-project.org/package=quantreg

19. Koenker, R., and Bassett, G. 1978. Regression quantiles. Econometrica 46:33-50

20. Madden, L. V., Pennypacker, S. P., and MacNab, A. A. 1978. FAST, a forecast system for Alternaria solani on tomato. Phytopathology 68:1354-1358.

21. Marín, J. E., Fernández, H. S., Peres, N. A., Andrew, M., Peever, T. L., and Timmer, L. W. 2006. First report of Alternaria brown spot of citrus caused by Alternaria alternata in Peru. Plant Dis. 90:686.

22. Martin, T. G., Wintle, B. A., Rhodes, J. R., Kuhnert, P. M., Field, S. A., Low-Choy, S. J., Tyre, A. J., and Possingham, H. P. 2005. Zero tolerance ecology: improving ecological inference by modelling the source of zero observations. Ecol. Lett. 8:1235-1246.

23. Mondal, S. N., Vicent, A., Reis, R. F., and Timmer, L. W. 2007. Efficacy of pre- and postinoculation application of fungicides to expanding young citrus leaves for control of melanose, scab, and Alternaria brown spot. Plant Dis. 91:1600-1606.

24. Paul, P. A., and Munkvold, G. P. 2004. A model-based approach to preplanting risk assessment for gray leaf spot of maize. Phytopathology 94:13501357.

25. Payne, A. F., and Smith, D. L. 2012. Development and evaluation of two pecan scab prediction models. Plant Dis. 96:1358-1364.

26. Peres, N. A., and Timmer, L. W. 2006. Evaluation of the Alter-Rater model for spray timing for control of Alternaria brown spot on Murcott tangor in Brazil. Crop Prot. 25:454-460.

27. Pryor, B. M., Davis, R. M., and Gilbertson, R. L. 1994. Detection and eradication of Alternaria radicina on carrot seed. Plant Dis. 78:452-456.
28. Reis, R. F., Goes, A. de., Mondal, S. N., Shilts, T., Brentu, F. C., and Timmer, L. W. 2006. Effect of lesion age, humidity, and fungicide application on sporulation of Alternaria alternata, the cause of brown spot of tangerine. Plant Dis. 90:1051-1054.

29. Ripley, B. 2012. tree: classification and regression trees. R package version 1.0-32. http://CRAN.R-project.org/package=tree

30. Rotem, J. 1994. The Genus Alternaria. Biology, Epidemiology and Pathogenicity. American Phytopathological Society, St. Paul, MN.

31. Simmons, E. G. 2007. Alternaria: An Identification Manual. CBS Fungal Biodiversity Centre, Utrecht, The Netherlands.

32. Solel, Z., and Kimchi, M. 1998. Histopathology of infection of Minneola tangelo by Alternaria alternata pv. citri and the effect of host and environmental factors on lesion development. J. Phytopathol. 146:557-561.

33. Timmer, L. W., Darhower, H. M., Zitko, S. E., Peever, T. L., Ibáñez, A. M., and Bushong, P. M. 2000. Environmental factors affecting the severity of Alternaria brown spot of citrus and their potential use in timing fungicide applications. Plant Dis. 84:638-643.

34. Timmer, L. W., Peever, T. L., Solel, Z., and Akimitsu, K. 2003. Alternaria diseases of citrus - novel pathosystems. Phytopathol. Mediterr. 42:3-16.

35. Timmer, L. W., Solel, Z., Gottwald, T. R., Ibáñez, A. M., and Zitko, S. E. 1998. Environmental factors affecting production, release, and field populations of conidia of Alternaria alternata, the cause of brown spot of citrus. Phytopathology 88:1218-1223.

36. Tsuge, T., Harimoto, Y., Akimitsu, K., Ohtani, K., Kodama, M., Akagi, Y., Egusa, M., Yamamoto, M., and Otani, H. 2012. Host-selective toxins produced by the plant pathogenic fungus Alternaria alternata. FEMS Microbiol. Rev. 37:44-66.

37. Vaz, S., Martin, C. S., Eastwood, P. D., Ernande, B., Carpentier, A., Meaden, G. J., and Coppin, F. 2008. Modelling species distributions using regression quantiles. J. Appl. Ecol. 45:204-217.

38. Vicent, A., Armengol, J., and García-Jiménez, J. 2007. Rain fastness and persistence of fungicides for control of Alternaria brown spot of citrus. Plant Dis. 91:393-399.

39. Vicent, A., Armengol, J., and García-Jiménez, J. 2009. Protectant activity of reduced concentration copper sprays against Alternaria brown spot on 'Fortune' mandarin fruit in Spain. Crop Prot. 28:1-6.

40. Vicent, A., Badal, J., Asensi, M. J., Sanz, N., Armengol, J., and GarcíaJiménez, J. 2004. Laboratory evaluation of citrus cultivars susceptibility and influence of fruit size on Fortune mandarin to infection by Alternaria alternata pv. citri. Eur. J. Plant Pathol. 110:245-251.

41. Vicent, A., Bassimba, D. D. M., Hinarejos, C., and Mira, J. L. 2012. Inoculum and disease dynamics of circular leaf spot of persimmon caused by Mycosphaerella nawae under semi-arid conditions. Eur. J. Plant Pathol 134:289-299.

42. Wang, X. F., Li, Z. A., Tang, K. Z., Zhou, C. Y., and Yi, L. 2010. First report of Alternaria brown spot of citrus caused by Alternaria alternata in Yunnan Province, China. Plant Dis. 94:375-375.

43. World Meteorological Organization. World Weather Information Service, Monthly Averages for the 30-Year Period 1971-2000. http://worldweather wmo.int/index.htm

44. Zhang, D., Hui, D., Luo, Y., and Zhou, G. 2008. Rates of litter decomposition in terrestrial ecosystems: global patterns and controlling factors. J. Plant Ecol. 1:85-93. 